A SELECTED BIBLIOGRAPHY:

REMOTE SENSING APPLICATIONS

IN GEOGRAPHY

U.S. GEOLOGICAL SURVEY

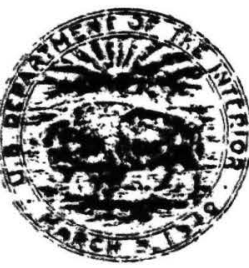





\title{
A SELECTED BIBLIOGRAPHY: \\ REMOTE SENSING APPLICATIONS \\ IN GEOGRAPHY
}

\author{
by W. J. Ripple I/
}

\section{$\checkmark$}

U.S. Geological Survey

Sioux Falls, South Dakota 57198

If Technicolor Graphic Services, Inc., Sponsored by the U.S. Geological Survey, Contract Number 14-08-0001-16439 
Abstract--_-_-_-_-_-_-_-_-_ 1

Introduction-- 1

Bibliography

Cartography--_-_-_-_--- 2

Demography/population-_-_-_ 4

Geomorphology-- 6

Land resource analysis-_-n 9

Land use/land cover-_-_-_ 12

Urban and regional planning-- 16 
A SELECTED BIBLIOGRAPHY:

REMOTE SENSING APPLICATIONS IN GEOGRAPHY

W. J. Ripple, Technicolor Graphic Services, Inc.

\section{ABSTRACT}

The bibliography contains 82 citations of selected publications and technical reports. The references deal with the application of remote sensing techniques to the collection and analysis of geographic data. All of the citations were published between January 1968 and July 1977 .

\section{INTRODUCTION}

This bibliography represents a selected list of references on the application of remote sensing techniques in geographic research involving the collection and analysis of spatial data. The bibliography is divided into the following categories: Cartography, demography/population, geomorphology, land resource analysis, land use/land cover, and urban and regional planning.

The bibliography is not intended to be all-inclusive, but rather a list of selected significant works published from January 1968 to July 1977. The major U.S. periodicals and symposium and professional meetings proceedings were examined, as were NASA listings of reports dealing with remote sensing. Also included in the bibliography are citations from University and corporate sources. 


\section{BIBLIOGRAPHY}

\section{Cartography}

Colvocoresses, A. P., 1972, Cartographic applications of ERTS imagery, in NASA Goddard Space Flight Center, Earth Resources Technology Satellite-1 Symposium, Greenbelt, Maryland, Sept: 1972, Proc.: p. 88-94.

--1974, Towards an operational ERTS - requirements for implementing cartographic applications of an operational ERTS-type satellite, in NASA Goddard Space Flight Center, Earth Resources Technology Satellite-1 Symposium, 3rd, Washington, D. C., 1973, Proc.: NASA SP-351, v. 1, sec. A, p. 539-546.

Colvocoresses, A. P., and McEwen, R. B., 1973, Progress in cartography, EROS Program, in NASA Goddard Space Flight Center, Symposium on significant results obtained from ERTS-1, New Carrol1ton, Maryland, March 1973, Proc.: NASA SP-327, v. 1, sec. B, p. $887-898$.

Henderson, F. M., 1974, Small scale thematic mapping: a case for radar imagery, in American Society of Photogrammetry fall convention, Washington, D. C., September 1974, Proc.: p. 155-169.

Poulton, C. E., 1973, A scheme for the uniform mapping and monitoring of Earth resources and environmental complexes using ERTS-I imagery: Berkeley, Calif., Earth Satellite Corp., 29 p.

Welch, R., 1973, Cartographic quality of ERTS-1 image, in NASA Goddard Space Flight Center, Symposium on significant results obtained from ERTS-1, New Carrollton, Maryland, March 1973, Proc.: NASA SP-327, v. 1, sec. B, p. 879-886. 
Wong, K. W., 1975, Geometric and cartographic accuracy of ERTS-1 imagery: Photogrammetric Engineering and Remote Sensing, v. 41, no. 5, p. 621-635. 


\section{Demography/population}

Anderson, D. E., and Anderson, P. N., 1973, Population estimates by humans and machines: Photogrammetric Engineering, v. 39, no. 2, p. 147-154.

Daya1, H. H., and Khairzada, B. A., 1976, The first national demographic survey of Afghanistan: The role played by air photos and photo-counting techniques: The ITC (International Institute for Aerial Survey and Earth Sciences) Journal, 1976-1, p. 84-97. Eyre, L. A., Adolphus, Blossom, and Amiel, Monica, 1970, Census analyșis and population studies: Photogrammetric Engineering, v. 36, no. 5, p. $460-466$.

Hsu, Shin-yi, 1973, Population estimation from ERTS imagery: Methodology and evaluation, in American Society of Photogrammetry annual meeting, 39th, Washington, D. C., March 1973, Proc., p. 583591.

Kraus, S. P., Senger, L. W., and Ryerson, J. M., 1974, Estimating population from photographically determined residential land use types: Remote sensing of the environment, v. 3, no. 1, p. 35-42. Murai, Shunji, 1974, Estimation of population density in Tokyo districts from ERTS-1 data, in Internat. symposium on remote sensing of environment, Michigan, 9th, 1974, Proc.: Ann Arbor, Environmental Research Institute of Michigan, v. 1, p. 13-22.

Ogrosky, E. E., 1975, Population estimates from satellite imagery: Photogrammetric Engineering and Remote Sensing, v. 41, no. 6, p. 707-712. 
Paul, C. K., and Landini, A. J., 1976, Remote sensing, land use, and demography - a look at people through their effects on the land, in American Society of Photogrammetry annual meeting, 42nd, Washington, D. C., February 1976, Proc., p. 349-367.

Thompson, D., 1975, Small area population estimation using land use data derived from high altitude aircraft photography, in American Society of Photogrammetry fall convention, Phoenix, Arizona, Oct. 1975, Proc., p. 673-696. 


\section{Geomorphology}

Allen, W. H., Martin, J. A., and Rath, D. L., 1973, Geologic ground and drainage patterns from ERTS-1 imagery in northern Missouri, in American Society of Photogrammetry symposium on management and utilization of remote sensing data, Sioux Falls, South Dakota, 1973, Proc., p. 333-341.

Baker, V. R., Holz, R. K., Hulke, S. D., Patton, P. C., and Penteado, M. M., 1975, Stream network analysis and geomorphic flood plain mapping from orbital and suborbital remote sensing imagery application to flood hazard studies in central Texas: Austin, Univ. of Texas, $187 \mathrm{p}$.

Bale, J. B., and Minch, J. A., 1971, Coastal and shore land forms of Baja California, Del Horte, Mexico: Riverside, Univ. of Calif., 84 p.

Bruce, W. D., and Howard, P. J., 1972, Geomorphic significance of surface drainage characteristics interpreted from ERTS-A simula-. tion imagery, in the first Canadian symposium on remote sensing, v. 1, p. $281-286$.

Coiner, J. C., 1972, SLAR image interpretation keys for geographic analysis: Lawrence, Univ. of Kansas, Center for Research, Inc., $116 \mathrm{p}$.

Dolar, R. D., and Heywood J., 1976, Landsat application of remote sensing to shoreline-form analysis: Charlottesville, Virginia Univ., $7 \mathrm{p}$. 
Erb, D. K., 1968, Geomorphology of Jamaica: Photogrammetric Engineering, v. 34 , no. $11, \mathrm{p} .1148-1160$.

Feyer, F., 1971, Photo interpretation applied to geomorphology - a review: Photogrammetria, v. 27, no. 1, p. 7-53.

Lewis, A. J., 1971, Geomorphic evaluation of radar imagery of southeastern Panama and northwestern Columbia: Lawrence, Univ. of Kansas, 166 p.

MacDonald, J. C., 1971, Mapping and landform analysis of coastal regions with radar: Geological Society of American bulletin, v. 82, p. 345-358.

McCoy, R. M., 1969, Drainage network and analysis with K-band radar imagery: Geographical review, v. 39, p. 493-512.

Moore, D. G., and Westin, F.*C., 1974, ERTS data as a teaching tool in regional physical geography with special reference to South Dakota State Univ., Remote Sensing Institute, SDSU-RSI-74-05.

Olsen, K. N., and Myer, M. P., 1976, Assessment of upper Mississippi River floodplain changes with sequential aerial photography, in American Society of Photogrammetry annual meeting, 42nd, Falls Church, Feb. 1976, Proc., p. 167-177.

Parry, J. T., and Turner H., 1971, Infrared photos for drainage analysis: Photogrammetric Engineering, v. 37, no. 10, p. 1031-1038. Pascucci, R. F., North, G. W., Albrizio, R. A., et. al., 1969, Geographic analysis of multiple sensor data from the NASA/USGS Earth Resources Program: Lexington, Massachusetts, Raytheon Company, 198 p. 
Wagner, T. W., and Hase11, P. G., Jr., 1973, The remote identification of terrain features and materials at Kansas test sites: " An investigative study of techniques: Ann. Arbor, Michigan Univ., Environmental Research Institute of Michigan, 55 p.

Woodman, R. C., 1973, To map the distribution of glaciofluvial deposits and associated glacial landforms: Augusta, Maine, Maine Transportation Department, Bureau of Highways, 42 p. 


\section{Land resource analysis}

Alexander, R. H., 1973, CARETS--an experimental regional information system using ERTS data, in NASA Goddard Space Flight Center, Earth Resources Technology Satellite-1 symposium, 3rd, Washington, D. C., 1973, Proc.: NASA SP-315, v. 1, sec. A, p. 505522.

Brooner, W. G., and Nichols, D. A., 1972, Considerations and techniques for incorporating remotely sensed imagery into the land resources conference, 1st, Tullahoma, Tenn., 1972, Proc.: Tullahoma, Tenn., Tennessee Univ. Space Institute, v. 1, p. 1-24.

Cosgriffe, H. R., Linne, J. M., and Meyer, M. P., 1973, Remote sensing applications to Northern Great Plains resources management, in American Society of Photogrammetry symposium on management and utilization of remote sensing data, Sioux Falls, South Dakota, 1973, Proc., p. 593-597.

Craib, K. B., 1972, The cost-effectiveness of high altitude systems for regional resource assessment, in Remote sensing of Earth resources conference, 1st, Tullahoma, Tenn., 1972, Proc.: Tullahoma, Tenn., Tennessee Univ. Space Institute, v. 1, p. 315337.

Federation of Rocky Moutain States, 1973, Interstate and federal test project for a land and resources information system for the Rocky Mountain region, in Land use papers 1972-73: Methods for state and industry planning: Denver, Federation of Rocky Mountain States, technical paper $4.107(5)$. 
Federation of Rocky Mountain States, 1977, Composite mapping system II user's manual: Washington, D. C., Economic Development Administration and National Science Foundation, Regional technical paper, 209 p.

Halpern, J. A., Alexander, L. D., and O'Regan, D. M., 1975, The application of remote sensing data to geographic-based information management systems, in Internat. symposium on remote sensing of environment, Michigan, 10th, 1975, Proc.: Ann Arbor, Environmental Research Institute of Michigan, v. 1, p. 351-358. Henderson, J. A., Jr., Baumgardner, M. F., and Walker, C. F., 1974, Preparing resource inventories in the southern Great Plains by machine-processing of ERTS-1 multispectral data, in Conference on remote sensing in arid lands, 4th, Tucson, Arizona, 1973, Proc.: Tucson, Office of Arid Land Studies, Arizona Univ., p. 57-69.

Hill-Rowley, R., Boylan, M., Enslin, W., and Vlasin, R., 1975, Improved resource use decisions and actions through remote sensing, in NASA Lyndon'B. Johnson Space Center Earth resources survey symposium, Houston, Texas, 1975, Proc., v. I-C, p. 1747-1767. Krumpe, P. F., Nichols, J. D., and Lauer, D. T., 1973, Analysis of wildland resources using manual and automatic techniques, in American Society of Photogrammetry symposium on management and utilization of remote sensing data, Sioux Falls, South Dakota, 1973, Proc., p. 50-66. 
Landgrebe, D. A., 1975, The application of remote sensing technology to the solution of problems in the management of resourees in Indiana: Lafayette, Indiana, Purdue Univ., Laboratory for Applications of Remote Sensing, $14 \mathrm{p}$.

Langley, P. G., 1971, Multistage sampling of Earth resources with aerial and space photography, in Monitoring Earth resources from aircraft and spacecraft, Washington, D. C., National Aeronautics and Space Administration, NASA SP-275, p. 129-141.

Lowe, D. S., Isten, I. B., Roller, N. E., et. al., 1974, Remote sensing in Michigan for land resource management: Ann Arbor, Michigan Univ., Environmental Research Institute of Michigan, $58 \mathrm{p}$.

Sellman, A. N., 1973, Land resources survey for the State of Michigan, in NASA Goddard Space Flight Center, Symposium on significant results obtained from the Earth Resources Technology Sate1lite-1, New Carrollton, Maryland, March 1973, Proc.: NASA SP327 , v. 1, sec. B, p. 1083-1090. 
Land use/land cover

Anderson, J. R., Hardy, E. E., Roach, J. T., and Witmer, R. W., 1976, A land use and land cover classification system for use with remote sensor data: U.S. Geological Survey professional paper 964, 28 p. Baldridge, P. E., Goesling, P. H., Leone, Frank, Minshall, Charles, Rodgers, R. H., and Wilhelm, C. L., 1975, Ohio's satewide land use inventory: an operational approach for applying Landsat data to state, regional, and local planning programs, in NASA Lyndon B. Johnson Space Center Earth resources survey symposium, Houston, Texas, 1975, Proc., v. 1-C, p. 1541-1552.

Bay, S. M., 1976, Final report and recommendations of the National Conference of State Legislators' task force on uses of satellite remote sensing for state policy formulation: Denver, National Conference of State Legislators, 257 p.

Befort, W. A., Heller, R. C., and Ulliman, J. J., 1977, Idaho landuse mapping from Landsat transparencies: Moscow, Univ. of Idaho, Forest, Wildlife and Range Experiment Station, Station Note no. 28. Brockman, C. E., and Brooner, W. G., 1975, Land use classification in Bolivia, in NASA Lyndon B. Johnson Space Center Earth resources survey symposium, Houston, Texas, 1975, Proc., v. 1-C, p. 18411861.

Dill, H. W., Jr., and Otte, R. C., 1970, Urbanization of lands in the western states: U.S. Department of Agriculture, Economic Research Service, ERS-428, $30 \mathrm{p}$. 
Ellefsen, Richard, and Peruzzi, Duilio, 1976, Land use change detection from Landsat and Skylab satellites, in Congress of the International Society for Photogrammetry, Helsinki, 13th, 1976, Proc., p. 1-6. Estes, J. E., Senger, L. W., and Thaman, R. R., 1973, Application of ERTST-1 satellite imagery for land use mapping and resource inventories in the central coastal region of California, in NASA Goddard Space Flight Center, Earth Resources Technology Satellite-1 symposium, 3rd, Washington, D. C., 1973, Proc.: NASA SP -315 , v. 1, sec. A, p. 457-490.

Garduno, Hector, Lagos, R. C., and Simo, F. G., 1975, Present and potential land use mapping in Mexico, in NASA Lyndon B. Johnson Space Center Earth resources survey symposium, Houston, Texas, 1975, Proc., v. 1-C, p. 1823-1839.

Genderen, J. L. Van, and Smith, T. F., 1975, A national land use survey of the developed areas of England and Wales by remote sensing, in Internat. symposium on remote sensing of environment, Michigan, 10th, 1975, Proc.: Ann Arbor, Environmental Research Institute of Michigan, v. 1, p. 383-392.

Henderson, F. M., 1975, Radar for small-scale land-use mapping: Photogrammetric Engineering and Remote Sensing, v. 1, no. 3, p. 307-319.

Hofstee, Paul, 1976, Actual space use map Enschede - urban 'Iand use' inventory with photo interpretation: The ITC (International Institute for Aerial Survey and Earth Sciences) Journal, 1976-3, p. $431-456$. 
Lins, H. F., Jr., 1976, Land-use mapping from Skylab S-190B photography: Photogrammetric Engineering and Remote Sensing, v. 42, поo. 3, p. 301-307.

Lucas, J. R., Taranik, J. V., and Billingsley, F. C., 1975, Land classification of south-central Iowa from computer-enhanced images: Iowa City, Iowa Remote Sensing Laboratory, Iowa Geological Survey.

Place, J. L., 1974, Change in land use in the Phoenix $(1: 250,000)$ quadrangle, Arizona, between 1970 and 1973--ERTS as an aid in a nationwide program for mapping general land use, in NASA Goddard Space Flight Center, Earth Resources Technology Satellite-1 symposium, 3rd, Washington, D. C., 1973, Proc., v. 1, sec. A, p. 393-423.

Simpson, R. B., Lindgren, D. T., and Goldstein, W. D., 1973, Evaluation of ERTS-1 data for acquiring land use data of northern Megalopolis, in NASA Goddard Space Flight Center, Earth Resources Technology Satellite-1 symposium, 3rd, Washington, D. C., 1973, Proc.: NASA SP-351, v. 1, sec. A, p. 371-381.

Tessar, P. A., Hood, D. R., and Todd, W. J., 1975, The South Dakota cooperative land use effort: a state level remote sensing demonstration project, in NASA Lyndon B. Johnson Space Center Earth resources survey symposium, Houston, Texas, 1975, Proc., v. 1-C, p. 1499-1523. 
Todd, W. J., Mause1, P. W., and Wenner, Kenneth, 1973, Preparation of urban land use inventories by machine-processing of ERTS MSS data, in NASA Goddard Space Flight Center, Symposium on significant results obtained from ERTS-1, New Carrollton, Maryland, March 1973, Proc.: NASA SP-327, v. 1, sec. B, p. 1031-1039.

Todd, W. J., 1977, A selective bibliography:- remote sensing applications in land use and land cover inventory tasks. (in preparation)

Vegas, P. L., 1974, A detailed procedure for the use of smal1-scale photography in land use classification: Houston, NASA Lyndon B. Johnison Space Center, NASA TND-7542.

Wray, J. R., 1970, Census cities project and atlas of urban and regional change, in NASA Manned Spacecraft Center annual Earth resources program review, 3rd, Houston, Texas, Proc., v. 1, p. 2-1 to 2-16. 


\section{Urban and regional planning}

Barr, D. J., and Miles, R. D., 1970, SLAR imagery and site selection: Photogrammetric Engineering, v. 36, no. 11, p. 1155-1170.

Barr, D. J., and Hensey, M. D., 1974, Industrial site study with remote sensing: Photogrammetric Engineering, v. 40, no. 1, p. 79-85.

Branch, M. C., 1971, City planning and aerial information: Cambridge, Massachusettes, Harvard Univ. Press.

Clark, R. B., and Mount, D. A., 1975, Planning applications of remote sensing in Arizona, in American Society of Photogrammetry fall convention, Phoenix, Arizona, Oct. 1975, Proc., p. 884-888.

Eastman Kodak Co., 1975, Aerial photography as a planning tool: Rochester, New York, 49 p.

Grey, A. L., Westerlund, F. V., and Hartlmueller, G. J., 1973, Applications of remote sensing in urban and regional planning, in American Society of Photogrammetry symposium on management and utilization of remote sensing data, Sioux Falls, South Dakota, 1973, Proc., p. 94-116.

Harting, W., 1975, Investigation of satellite imagery for regional planning: Albany, New York, Tri-State Regional Planning Commission, $72 \mathrm{p}$.

Hedrick, Wallace, Cunningham, Paul, Shay, J. R., Lake, B. L., and McCormick, Michael, 1976, Landsat: Pacific Northwest area using satellite data for planning, resource management: Practicing Planner, v. 6, no. 5, p. 18-26. 
Higgs, G. K., 1975, Multispectral approach to urban neighborhood analysis and delineation, in American Society of Photogrammetry fall convention, Phoenix, Arizona, Oct. 1975, Proc., p. 444-465. Hultquist, N. B., Rushton, G., and Schmitt, R. P., 1971, Identifying and forecasting change in a regional system of urban places, in Internat. symposium on remote sensing of environment, Michigan, 7th, 1971, Proc.: Ann Arbor, Environmental Research Institute of Michigan, v. 2, p. 989-1003.

Nichol, J. E., 1974, Landtype analysis for regional land use planning, from photomorphic mapping: an example for Boulder County, Colorado, in Internat. symposium on remote sensing of environment, Michigan, 9th, 1974, Proc.: 'Ann Arbor, Environmental Research Institute of Michigan, v. 1, p. 589-596.

Paul, C. K., Landini, A. J., and Diegert, Carl, 1975, Remote sensing application for urban planning: the LUMIS project: Remote sensing of the elctromagnetic spectrum, v. 2, no. 4, p. 8-31. Smedes, H. W., Nez, George, Salmen, Larry, Turner, A. K., Lutzen, E. E., and Reed, J. C., Jr., 1974, Land use planning aided by computer cellular modelling/mapping system to combine remote sensing, natural resources, social and economic data, in International symposium on remote sensing of environment, Michigan, 9th, 1974, Proc.: Ann Arbor, Environmental Research Institute of Michigan, v. 1, p. 289-298. 
Westerlund, F. V., 1972, Remote sensing for planning: a bibliography and review of literature: Seattle, Washington Univ., Dept. of Urban Planning, Urban Planning Development Series no. 10, 220 p. 